\title{
Stormagten vi ikke orker
}

For nylig besluttede Danmarks Radio at nedlægge sin faste korrespondentpost i Moskva - ligesom TV2 gjorde det for nogle år siden. Også flere aviser har i de senere år nedprioriteret dækningen af Rusland og nedlagt deres faste korrespondentpost i Moskva. På gymnasier og højere læreranstalter er det samtidig blevet sværere at få elever og studerende til russisk. Og endelig forlyder det, at forsvaret i nærmeste fremtid vil ophøre med at uddanne sprogofficerer i russisk.

Med erhvervslivet som undtagelse er vi i Danmark åbenbart ved at tabe interessen for den stormagt, der fuldkomment dominerede vores sikkerhedspolitiske overvejelser i anden halvdel af det tyvende århundrede. Årsagen ligger lige for: Rusland truer os ikke længere direkte. Omdrejningspunktet for international politik er ikke længere den Kolde Krig og ikke udviklingen i det post-sovjetiske område, men i voksende grad bekymring for stabilitet og religiøs ekstremisme i det område, som i dag kaldes 'det bredere Mellemøsten'.

Putins skarpe Wehrkunde-tale i München i februar bebudede ikke desto mindre en ny international russisk aktivisme, der også kan få vældig betydning i såvel Mellemøst- en og Centralasien som i kampen mod international terrorisme. Den ny kurs i Putins Rusland kan således også blive i ildevarslende modstrid med vestlige interesser, herunder Danmarks. I dette relancerede nummer af Udenrigs fokuserer vi derfor på udviklingen i Rusland og det postsovjetiske område og bringer Putins forsvar for en multipolær verden.

Udenrigs vil fremover udkomme med fire større udgaver om året, hver gang med fokus på en væsentlig tendens i international politik. Samtidig vil Udenrigs fast lægge øre til Danmarks stemmeføring i international politik. Vi genopliver den traditionsrige klumme 'Verdenshavet og Frederiksholms Kanal'. Og vi vil åbne et vindue til folketingets spørgetid, når der krydses klinger om internationale spørgsmål.

Udenrigs vil samtidig - og fortsat være hjemsted for kyndige analyser og fortolkninger af den internationale udvikling og dansk udenrigsog sikkerhedspolitik.

\section{Redaktionen}

Med dette nummer udtreder Torben Krogh af Udenrigs' redaktion efter 13 airs aktiv indsats. Herefter vil redaktionen bestå af Brita V. Andersen, Anna Libak og Anders Jerichow. 